\title{
Democracy and the Armed Forces: Lessons from the Coups of Egypt in 2013 and Turkey in 2016
}

\author{
Muhamad Rofiq \\ Faculty of Politics and Social Science \\ Universitas Muhammadiyah Yogyakarta \\ West Ringroad, Yogyakarta 55183, Indonesia \\ muhammadrofiq@umy.ac.id \\ Submitted: 01 September 2016, Accepted: 2 December 2016
}

\begin{abstract}
Abstrak
Tulisan ini menganalisa secara komparatif kudeta militer yang terjadi di Mesir tahun 2013 dan Turki tahun 2016. Dua pertanyaan yang didiskusikan adalah: pertama, terkait dengan faktor yang mendorong terjadinya dua kudeta tersebut, dan kedua, alasan mengapa dua fenomena tersebut berbeda, kudeta berhasil di Mesir dan gagal di Turki. Untuk menjawab dua pertanyaan tersebut, tulisan ini melihat sejumlah aspek yang terkait dengan kondisi sosial dan kekacauaan politik menjelang kudeta, mulai dari krisis ekonomi, kebijakan non-demokratis, sikap masyarakat sipil sampai karakteristik angkatan bersenjata kedua negara. Dua kudeta milter yang terjadi ini menunjukkan bahwa proses demokratisasi di dunia muslim sesungguhnya sangat ditentukan oleh aktor politik, di mana peran terpenting dimainkan oleh angkatan bersenjata, selain itu juga dibentuk oleh doktrin Islam sendiri.
\end{abstract}

Kata kunci: Kudeta Militer, Arab Spring, Timur Tengah, Angkatan Bersenjata, Demokrasi

\begin{abstract}
This article seeks to comparatively examine the military coups happening both in Egypt in 2013 and Turkey in 2016. Two problems discussed in this paper are: firstly, concerning the trigger causes behind the two coups and, secondly, the reason why those phenomena are different, in which the coup was successful in Egypt and failed in Turkey. In order to answer these questions, this paper reviews some aspects related to social condition and the political turmoil before the coups exploded, ranging from the economic crisis, the autocratic policies, the stance of civil society, until the nature of the armed forces itself. The two military coups indicate that the democratization process in the Moslem world is highly determined by the political actors, in which the most important parts of them is the armed forces, in addition, to be shaped by the doctrine of Islam itself.

Keywords: Military Coup, Arab Spring, Military Forces, Middle East, Democracy
\end{abstract}

\section{INTRODUCTION}

Some Western scholars believe that Islam and democracy are incompatible in essence (Lewis, 2010; Fish, 2002). It is suggested that the principles of democracy and the basic nature of Islamic polity are extremely different. In response to this, many other scholars formulate feedback theory, saying that it is not the doctrine of Islam that leads Muslim states become undemocratic. Bayat for example, maintains that it is the intellectual belief and political capacity of the political actors that account for the absence of democracy in a Muslim country, instead of doctrine of
Islam itself (Bayat, 2007: 17). Likewise, Ahmed Kuru proposes another notion concerning the reason behind the absence of democracy. He believes in geographic and geologic determinism, saying that the abundance of natural resources, regardless of whether it is in a Muslim or non-Muslim country, creates the undemocratic system of a country. This lavishness of wealth, he argues, establishes patron-client relation between the ruled and the ruler (Kuru, 2014). This theory implies, if the economy of a state relies on taxation, rather than natural resources, then democ- 
racy will exist strongly. Lastly, Esposito contends that like all other religions, Islam has a full spectrum of potential symbols and concepts for democracy.

However, he argues, each Muslim-majority country has a distinctive experience in achieving a democratic system that cannot be assessed by the western definition of democracy (Esposito, 2016). Therefore, the absence of democracy in some Muslim countries does not necessarily mean that Islam contradicts democracy.

Recently, we witness the rise of hope for democracy in Muslim countries, especially in the Middle East since the Arab Spring which started in 2011 and has toppled the autocrat regimes in the region. Ranging from Tunisia, followed by Egypt, Libya, Yemen and Syria, the wave of revolution gave a new optimism for political change in those Arab countries amid crisis. After six years, the achievement of each revolution differs from one country to another, but mostly was still beyond expectation. Accordingly, Libya and Yemen suffered from civil wars, despite the fact that Qadafi and Saleh had been overthrown. Syria became the field of proxy war between the two blocs of Muslim country and the dictator, Assad who remains in his throne. Only the experience of Tunisia demonstrated the positive accomplishments of democracy and thus became the model for other countries in Middle East as well as North Africa.

In the case of Egypt, the revolution was hijacked by the military generals. At the beginning, given its position as the most powerful and influential Arab country at the time, there existed a greater expectation for the change. In the early 2011, when the protestors who gathered from various backgrounds and successfully ousted Mubarak - the tyrannical ruler for 30 years-, many believed that the future of Egypt would be brighter. This was subsequently and further rationalized by the achievement, whereby for the first time in the history of Egypt, a fair presidential election was magnificently held. However, what happened in reality was the opposite of the hope. In fact, political and social culture of Egypt was not ready enough to embrace the true democratic system. Finally, in the name of stabilizing the political situation in Egypt, military generals raised a coup which ousted the first democratically elected president in the country. Consequently, the result of the military coup marked the turning point of Egypt's immature democracy and heralded a return to autocrat regime.

After the experience of failed democracy in Egypt along with in other Middle East countries during the Arab Spring, Turkey then became the next hope for achieving democratic political change. Many analysts believe that Turkey has succeeded in transforming not only their economic condition, but also the face of Islamism (Dagi, 2013). It is no doubt that the person behind the rising optimism of democratization in Turkey was the former prime minister and now the current president, Recep Tayib Erdogan. There are at least two strong reasons why this figure is worthy of respect and why he gained support of the Turks several times in the elections. Firstly, Erdogan was the first strong leader in Turkey who could weaken the role and influence of the military. It seems that the Turkey population has no more faith in the armed forces. The reason being that for almost a century the military had led the country within a secular system and the fate of Turkey remained unfortunate. Secondly, Erdogan has productively improved the economy of Turkey. Before the Erdogan presidency, Turkey was a weak state. But because of his strong commitment to be part of the European Union (EU), coupled with the strong and effective leadership, Turkey then became one of G-20 (Patton, 2006). However, after three periods of leadership, Erdogan began to show distinct authoritarian tendencies. Thus, this situation prompted the military to undertake the coup which dramatically occurred in the last $15^{\text {th }}$ July. Though the attempted coup failed, many still believe that the democratization of Turkey is under threat and may be experiencing a setback.

In the wake of reflections about the failed military coup in Turkey, there occur some writings that intended to find similarities in its failure with that of failed coup in Egypt. While some emphasize its similarities over the actual differences, other does the opposite (Shapiro, 2016; Ashour, 2016). Similarly, 
this article will compare the military coups that occurred in both Egypt and Turkey, but in a more depth analysis. The examination of these two coup d'états is justified by the following reasons. Firstly, because they are remarkable events in the history of democratization in the Muslim world. Although we will never refer to the thesis of Huntington about discordancy between democracy and Islam, these two experiences showed that the process of becoming a democratic country is still a faraway off and will take long time to achieve. In addition, by examining the two coups, we may be able to understand the map and the future of democracy in the region. Secondly, this writing will aim to propose an answer to the question "why the coup, as the serious constraint of democracy, happened recurrently in the Muslim world".

Given the considerations as above this paper will answer these two following questions: Firstly, what were the causes for the coup of Egypt and Turkey? Secondly, why was the military coup successful in Egypt while failed in Turkey? In order to answer these proposed questions, this paper will reveal similarities and differences between the military coups of both Egypt and Turkey and examined them comparatively.

\section{ANALYSES}

\section{THE ECONOMIC SITUATION}

Besides the different endings of both coups, in fact there are several other points that distinguish the military coup of Egypt in relation to that of Turkey. The most important point to consider before any other factors, is the triggering factor of the coups, integrated within an evaluation and comparison of the economic achievements of both ruling regimes. Morsi, due to his short government, failed to overcome the economic crisis that Egypt had been suffering since the fall of Mubarak. The New York Times even named the situation as the worst economic crisis since 1930 s (Kingsley, 2016). The crisis was marked by the presence of the rising unemployment of youth, a drastic fall in both foreign investment and revenues from tourism, followed by a $60 \%$ drop in foreign exchange reserves, 3\% drop in growth, and a rapid devaluation of the Egyptian pound (Kingsley, 2016). The unemployment figures in the time of the Morsi Presidency reached 850,000 people (Singh, 2013). Moreover, at the same time, the cost of living soared tremendously and resulted in ordinary Egyptians living under unbearable pressure. In general terms, during the Morsi's term the economy was in a radical decline.

Enduring this situation, Egyptians showed and expressed their frustration and anger toward the governing regime, even though Morsi's tenure was still only a year old. This was because he was the only one who could be blamed. However, there was another theory which existed, that it was military and other opponents of Morsi from the remnants of the previous regime who had purposely plotted the economic crisis. There were several facts that affirm this suspicion, such as the sudden disappearance of a gas line during the turmoil and the resultant appearance of power cuts (Maass, 2013). Above all, regardless of who were responsible, the crisis was not rectified. The Egyptian people, who were actually highly pragmatic and not ideologically attached to Morsi, became intolerant of the crisis. As a result of the instability and this economic crisis, the Supreme Council of Armed Forces (SCAF) considered themselves to be justified to seize the power.

Unlike the Egypt, the economy of Turkey during the tenure of Erdogan was quite positive. Erdogan and his party, Justice and Development Party (AKP), significantly raised the social welfare of the nation. During his reign, there has been a great success in terms of economic stability and improvement (Yulek, 2015). Perhaps this is partly due to his long period of administration, starting from 2002 to 2014. It is acknowledged that since he came to power, the economic growth of Turkey has averaged some 5\%. Moreover, inflation has been controlled. Maybe this was just possible because his strong commitment to be a member of European Union (EU) (Ismahan, 2016).

In 2016, despite the slight decrease in economic development, on account of some acts of ISIS terror 
and the worsened tie with Russia, the overall economic conditions in Turkey were actually still positive and satisfactory enough for Turks. This economic achievement was undoubtedly a strong factor that strengthened the bargaining position of Erdogan with his political enemies. In relation to this, an analyst suggests that the handout that Turks receive from their government, not Islamism ideology, was the cause most liable for improved support from Turks to Erdogan and contributed a real constraint upon the military's potential efforts to topple him and bring him down (Emre, 2016).

However, there is still one remaining question. But why the fact that the economy of Turkey was strong and not in crisis, did not prevent the military from undertaking the coup? At this point, we can assume that the spectacle used to understand the Egyptian coup, i.e. economic determinism, is useless.

\section{THE NATURE OF OPPOSITION MOVEMENT}

The second matter that distinguishes the experience of Egypt and Turkey is the nature of opposition movement in terms of their view toward the military coup. As the ruling regimes, Morsi and Erdogan were surrounded by the oppositional forces. However, unlike Erdogan who had enough strength around him, Morsi was almost without allies. As a matter of fact, Morsi's administration witnessed not only the absence of the so called "loyal opposition", but also the existence of "dedicated partners". In the beginning of his term, Morsi established a coalition comprising of his party, Freedom and Justice Party (FJP) and al-Nour party, another Islamist political group in Egypt.

However, in the course of time, when Morsi seemed to have lost legitimacy, al-Nour broke the coalition, which left Morsi behind and alone. Surprisingly, the al-Azhar institution, which had strong influence on the civil society of Egypt, also abandoned Morsi, arguing that by doing so they were avoiding civil strife. The fact that Morsi was an Islamist political leader was not taken into consideration by sheikh al-Azhar when he justified the right of the army to topple Morsi.

In addition, mention must be made of the political behavior of Morsi's opposition. They did not only dissent every single of Morsi's policies, but more than that, they also set up the Tamarrod movement with the main goal of removing Morsi altogether. Overall, Morsi faced a very strong opposition movement that consisted of many groups including the remnant of Mubarak bureaucrats, the secular or leftist groups and the youth movement. The main objective of the first opposition group was to defend the Mubarak legacy from every radical policy coming from Morsi, while objective of the secular or leftist groups was to separate the national identity from Islamism ideology. Meanwhile, the youth movement was motivated mainly by their disappointment with Morsi's tyrannical tendencies. In addition, Morsi also witnessed betrayal by the intelligentsia, who in their discourse always spoke about democracy but their behavior was less than democratic. Above all, Morsi antagonized the military corps who had their own interests, which were to preserve their privileges within Egyptian economy and politic. Finally, with the accumulation of the withdrawal of allies, the absence of support from al-Azhar in addition to the lack of loyal opposition ultimately, the coup was instigated by the military.

The Turkey's experience was different to that of Egypt. Erdogan is a strong leader. Some writers suggest that his strength is only comparable to Mustafa Kamal Ataturk, the founder of modern Turkey (Kuru A., 2015). Erdogan won the election in the four consecutive elections. In the last election held in 2014, Erdogan's party gained 52 percent of the votes. In the 2011 election, he also received half of Turkey's citizen's votes. This support made him quite secured from any attempt by the military to instigate a coup. Apart from this however, there are actually several groups who were always critical of Erdogan. The most prominent among these was the secularist group who embraced the ideology of Kemalism. Erdogan's oppositionists are represented by the Republican People's Party (CHP), the Nationalist Movement Party (MHP) and the Peoples' Democratic Party (HDP). Unpredictably, however, not a single 
opposition party supported the attempted coup. Though they were in opposition to Erdogan, even within that context they refused to support military coup which they thought would result in destroying the democracy of the country. They believed that the price Turkey would pay would be considerably higher if a civil war occurred (Daily Sabah Politics, 2016). In fact, this phenomenon is very surprising, as within this highly polarized political landscape, the opposition movement had bound themselves with the national interest of Turkey.

\section{THE UNITY OF MILITARY}

Another remarkable feature that differentiates the coups of each country is centered on the unity of armed forces. It is worthwhile to note that in both contexts, the military have strategic positions, as the guardian of secularism in Turkey's case and in Egypt's case, as the owner of and controller power over the economy of nation. In addition, both military have had a long successful history in terms of overthrowing their respective governments. The armed forces of Egypt ousted King Faruq in 1952, which ended the system of monarchy in the country, and finally in 2013 the Egyptian army ousted the first democratically elected President. The army of Turkey had had greater experiences in terms of removing rulers, starting from 1960 when a coup that ended with the execution of Adnan Manderes, continued by the smooth coup in 1970 and followed by the bloodiest one in 1980, which executed 50 persons. The last attempt of coup before Erdogan's administration occurred in 1997 (Emre, 2016). Prior to the 2016 coup, the Turkey military has also attempted several times to overthrow Erdogan's government, namely in 2007, 2012, and 2013 (Espostio, 2016: 41). Interestingly in each attempted coup, however, Erdogan has successfully eliminated the involved military officers.

In regards to the latest coup, it is highly noticeable that military generals were divided. It appears there were only a small number of military officers who supported the removal of Erdogan. More importantly, also the highest general in the Army rejected the coup.
As a matter of fact the coup movement was led by Colonel Muharrem Kose. The disunity of military forces is without a doubt the most determining factor behind the failure of the coup. The important relevant question related to the disunity is, why was there a split among them? There are at least some possible answers for this. Firstly, the conviction by Erdogan was that those who rebelled against him were the followers of Gulen and they were a small quantity. This means that Erdogan acknowledged that the army has been infiltrated. However, there are many doubts concerning this accusation, given that Gulen is a moderate person who always condemns and resists military influence in the political activities of the state (Fuller, 2016). Secondly, the split among Turkey soldiers stems from their view of Erdogan's leadership. Some perhaps respected his positive achievement, especially in terms of economic matters, while others saw and objected to his authoritarian tendency. Thirdly, majority of army officers who resisted the coup, more than likely considered the limited possibility of a successful coup, taking into account the failed previous attempts which ended up with total detention of the officers by Erdogan. Those who fought against him, therefore, had no settled and clear plan, only an immature plot.

In comparison, in its attempted Egyptian coup, the Egyptian army was more solid and unified than the army in Turkey. Despite the fact that the Abdul Fattah al-Sisi, the military general who deposed Morsi, was a new commander of SCAF as well the youngest of them and who replaced the old field Marshal Mohammed Husein at-Thanthawi, this did not prevent the more senior officers from obeying him. As a matter of fact, the event of any split among Egyptian military had never occurred since the era of President Anwar Sadat.

Taking into consideration on this fact, the same question arises, why was no similar division among the SCAF of Egypt? There are several possible answers for this. Firstly, it was due to strong position of SCAF under strong generals itself. In the wake of Arab Spring, according to the new Egyptian Constitution, 
the army still could enjoy the privileges of power where they could have control over their own military affairs. Unlike the Turkish Army, which in the course of time had been weakening by Erdogan, the SCAF of Egypt is still highly untouchable even until now. In addition to this, they also receive annual military aid from the USA. Secondly, because since the era of the Nasser presidency, the country had been led by the presidents whose background was also military. Under the tenure of military presidents, the army had easily consolidated themselves. This is incomparable to the military situation in Turkey where a split occurred because the army was led by the civilian. In conclusion and more importantly, the unity of the army eased the process of the coup d'état of President Morsi.

\section{THE CIVIL RESPONSE}

Egyptian people, with the influence of al-Azhar are largely an Islamic society. To some extent, this is similar to the Turks, who recently and especially after AKP's effect, became more religious than in the previous decades. Although similar in terms of religiosity, however, the responses of the two societies to the coups were different. Egyptian clerics, based on their long historical tradition of the Asharite school of thought they had been embracing, issued a fatwa and delivered opinions supporting the conduct of General al-Sisi (al-Azami). They argued, that in order to avoid fitna (civil disorder), they needed to endorse military action (al-Azami, 2015). This gave the justification for the masses to gather in Tahrir Square. No matter how democratic Morsi was elected, they considered that his presidency had lost its true legitimation because it lacked evidence of the support of the people. Sheikh al-Azhar, Ahmed Toyib, along with the Christian Coptic leader all stood behind al-Sisi in legitimizing his position and when this General declared the deposing Morsi (Shahine, 2016). Syekh Ali Gom'ah, the former mufti of Egypt, also gave a speech to the military troops supporting their action in dissolving the mass demonstration and justifying that the using of violence resulted in the death of thousand people (al-Azami, 2015). There was only dissenting opinion for this coup and from one Egyptian scholar, Yusuf Qaradawi. However his voice was neglected and he was lack of influence. His ineffectiveness was perhaps due to his residence being outside Egypt and his tendency to support the Moslem Brotherhood from where Morsi originated.

Unlike the Moslem scholars of Egypt, those of Turkey rejected the coup. Moreover, unlike ulama of al-Azhar who quoted the discourse of ilm kalam (Islamic theology) pertaining to legitimate ruler and the kharijite (rebellious), there was no theological consideration or justification behind the positive stance of Turk clergies. This was highly likely explained by the fact that Turkey itself was a secular state, so that the use of specific religious arguments in political debate is uncommon. In addition, it was still doubted that it was effective. However, to some extent, those who resisted the coup still used general Islamic expressions, such as the slogan of Allahu Akbar (God is the Greatest) (Tremblay, 2016). Above all, the support of Mehmet Gormez, head of the Religious Affairs Directorate for Erdogan and Erdogan's call for Turks to come to street, is clear evidence that the civil society as well as religious groups were resisting the coup. It is also highly likely, however, that the resistance of all Turks was not because of religious consideration although religion slogan was vocalized, but rather based on pragmatic reasons and considerations that living under military regime would worsen the situation. Also, the resistance of the Turks to the coup did not necessarily mean that they supported Erdogan, but rather their overall propensity toward democracy.

\section{THE UNDEMOCRATIC POLICIES}

Erdogan was the pride of Turkey in his first two terms. However, according to Ahmed Kuru, after 2011, although Turkey still experienced stunning economic growth, Erdogan had moved toward authoritarianism, Islamist populism and crony capitalism (Kuru A., 2015). Prior to the coup of 2016, there were several actions by Erdogan that crushed the democracy in Turkey. In 2012, for example, Erdogan proposed amendment of the constitution, trying to 
create a super powerful President who could legislate when the parliament was not in session and who was able to appoint two-thirds of the high court judges (Espostio, 2016: 41). As a result of those actions, Erdogan was charged by the opposition of strengthening the Presidency over the parliamentary system. He was accused of trying to fuse the executive with the legislative and judiciary. However, Erdogan frequently used the language of Western conspiracy theory in order to face his opponents.

In 2013, Erdogan was involved in a serious clash with his opponents because of his policy removing a park in Istanbul and replacing it with a mall and residency. Erdogan threatened the protestors by labeling them as secularists and under the influence of alcohol. In the same year, Erdogan was accused by the prosecutors of corruption on several issues, for example in government tenders. As a result, Erdogan reassigned hundreds of prosecutors and thousands of police officers. When the recording of his conversation about his corruption spread in the social media, he temporarily shut down Facebook, Twitter and YouTube. In addition, through the AKP media, Erdogan created an opinion that the money confiscated by the police was actually for Islamic services. Moreover, following the critical stance of Hizmet followers, Erdogan declared that Hizmet movement was a terrorist organization. Hundreds of members of the movement, which consists of judges, military generals, police officers and the ordinary followers, were detained. Gulen himself was painted by Erdogan media as a freemason trying to assassinate his daughter. In fact, this despotic attitude of Erdogan was another important and responsible factor behind the coup (Kuru A., 2015: 21).

With regards to Egypt, despite the fact that Morsi had only been seated in the Presidency chair for a year, he had issued some undemocratic policies. In response, there were several factors that triggered the anger of society towards Morsi and which ended up with his ousting. Firstly, he failed in accommodating a large number of important groups in his cabinet team. Out of 35 of his ministers, he neglected a youth representative and a woman as minister as well as a Christian as Vice President. His team consisted mainly the members of FJP, which was 12 out of 35 (VOA, 2013). In November 2012, Morsi issued a constitutional decree that enhanced his power and also included a ban on judicial review of all his policies as a president until the Egyptian constitution had been passed. His decrees also included the immunization of the Constituent Assembly and Shuria Council from possible dissolution. Morsi was also accused of attempting to control every aspect of the government and including that of public life (Espostio, 2016: 223). These dictatorial policies instigated the masses to conduct a huge protest. The armed forces utilized this opportunity. Finally, on July 3, 2016, al-Sisi, the commander of SCAF announced, that besides suspending the Constitution and removing Morsi from power, he also would appoint the head of the Constitutional Court, Adly Mansour, as the Interim President.

\section{THE ABSENCE OF THE UNIFYING IDEOLOGY}

If we delve into the coups in both countries, actually one of the indirect causes of both Egyptian and Turkish turmoil was the debate over the ideology of the state. This stemmed from the absence of the unifying ideology that would unite all the ideological groups that existed in each country. In the case of both Egypt and Turkey, the absence of this uniting philosophy in each country led to high levels of tension and division, especially among educated people, about national identity, and in turn, contributed significantly to instigation of coups.

Ideologically, Egyptians are divided into several factions, being Islamist, secularist, leftist and Coptic who account for $10 \%$ of Egyptian population. The Islamist themselves differ with in and from one to another. In the wake of January 2011 revolution, there were two Islamist parties established, namely al-Nour party, who resort to a conservative-salafist understanding of Islam and Freedom, and Justice Party established by the Moslem Brotherhood, in which its ideology was more moderate. Both parties were 
unified by the notion that they wanted to Islamize the country, irrespective of their differing methods in formal and cultural ways respectively.

On the other side, the other ideological groups were always in fear of the Islamists whom they accused as being an authoritarian. There was a conviction among non-Islamist politicians that when an Islamist sits in the position of power, he will transform into a despotic ruler (Delkhasteh, 2016). Non-Islamic groups also were concerned and worried about a formal implementation of Shariah. The picture of Iran that lives under the Islamist autocratic leadership appeared in their imagination. These groups rejected the Islamist parties, which they viewed as a politicization of religion and which, according to them, would lead primarily to abuse of power and monopoly of religion over the State. Therefore, when victory was gained by the Islamists in 2012 election, there immediately emerged a phobia and paranoia within these groups in Egypt. This resulted in non-Islamists activists carrying out radical movements with the ultimate goal of deposing Morsi and eradicating the Islamist groups.

As far as the Turkey was concerned, with the fall of Ottoman Empire, modern Turkey was founded as secular state in 1924. Subsequently, secularization was enforced from top up to bottom down, in which the state imposed secularism rigorously on the people, not only as a value of the political system, but also as a way of daily life. As a response to this, in the history of Turkey, we have seen several endeavors by the Islamists to introduce a more Islamic identity and weaken the secular influence within politics. It is worth noting that, those who live in countryside of Turkey, actually never accepted secularization in cultural life (Esposito, 2016: 29). All of the efforts of Islamization, however, resulted and ended with a coup. To mention more specifically, this happened to Necmetic Erbacan, the previous Prime Minister of Turkey, who was overthrown three times by a military coup, namely in 1970, 1980 and 1997. Those coups were justified by the military by claiming an accusation of violation of the Turkey Constitution.

Learning from several coups that have happened in the history of modern Turkey and which stemmed, primarily by the desire to revert to basic philosophy of the state, it can be said that the absence of unifying ideology among societies was also the determinant cause of those coups. In the case of military coup 2016, the military's desire to re-secularize the country also occupies an important factor behind instigation of the coup. It is true that there were several possible reasons that prompted some officers of Turkey military to undertake coup. Among prominent theories of the underlying factors behind current coup were firstly, it was undertaken by the military officers because they were infiltrated by Hizmet movement founded by Fethullah Gulen. Erdogan himself formulated this theory. However, there are some absurdities in this theory namely, the fact that Gulen himself is civilian man living abroad and Hizmet was already banned in 2013 (Fuller, 2016).

Second, there was a conspiracy theory where the Western countries were violating the face of a Muslim country. The followers of Erdogan also proposed this theory. However, there was no evidence for this theory. Thirdly, what seems to be the most convincing theory for me is the desire of armed forces themselves to restore the face of Turkey as a secular state, after it had been "shattered" by the soft Islamisation of Erdogan, and to retrieve the superiority of military forces. The reasons for this theory are: firstly, it is in line with the previous experiences of coups in Turkey and the fact that, in the course of time and under the Presidency of Erdogan, the military had been increasingly weakened.

\section{CONCLUSION}

In conclusion, there are several factors that contribute to the prompting of a military coup in Egypt or Turkey. In the case of Egypt, those factors are: the economic decay after the fall of Mubarak, the ambition of military forces to preserve their political and economic interests, and the traditionalist view and pragmatic behavior of 'ulama as well as the fear of Islamism from the secularists and the leftist. This was further nourished by the fact that Morsi behaved 
undemocratically. Regarding the context of coup in Turkey, the coup was triggered mainly by the army, who wanted to re-elevate their position after it had been weakened by Erdogan. In addition, the coup was also motivated by the desire of the army to retrieve secularism as the basic philosophy of the country's leadership, after it had been undermined with strong Islamization by Erdogan. The tendency by Erdogan toward authoritarianism after his second period also played a significant role in prompting the military force to undertake the coup.

While the military coup in Egypt was successful, that of Turkey failed. The success story of the military coup against Morsi originated from the unity of military officers, despite the fact that the army commander was still new seating in his position. It was also successful due to the strong support of the civil society with the clergy endorsement and the approval of all political parties. Meanwhile, the failure of the coup d'état in Turkey was caused by the split among army officers along with the strong refutation from society as well as the opposition parties. The fact that Erdogan has been charged previously by the corruption scandal and the violation of human rights still did not prevent him from getting strong back up and support.

\section{REFERENCES}

BOOKS

Bayat, Asef. 2007. Making Islam Democratic, Social Movements and the-Post-Islamist Turn, Stanford California Press.

Dagi, Ihsan. 2013. Post-Islamism a la Turca. In Bayat, Asef (ed.). PostIslamism, The Changing Faces of Political Islam. Oxford University Press.

Esposito, John L., Sonn, Tamara, and Voll, John O.. 2016. Islam and Democracy after the Arab Spring, Oxford University Press.

Fish, M. Steven. 2002. Islam and Authoritarianism. World Politics 55, October.

Kuru, Ahmad T.. 2014. Authoritarianism and Democracy in Muslim Countries: Rentier States and Regional Diffusion. Political Science Quarterly, Volume 129, Number 3.

Kuru, Ahmed T. 2015. The False Promise. Critical Muslim 16, OctoberDecember.

Kuru, Ahmed T. Turkey's Failed Policy toward the Arab Spring: Three Levels of Analysis. Mediterranean Quarterly 26:3. DOI 10.1215/ 10474552-3145779.

Lewis, Bernard. 2010. Faith and Power, Religion and Politics in the
Middle East. New York: Oxford University Press.

Patton, Marcie J.. (2006). The Economic Policies of Turkey's AKP Government: Rabbits from a Hat?. The Middle East Journal 60:3, Summer.

\section{INTERNET}

Al-Jazeera interview with Murat Yulek. Erdogan's Turkey: An Economic Success Story?. (Online), (http://www.aljazeera.com/programmes/ countingthecost/2015/11/erdogan-turkey-economic-success-story151108121817800.html, accessed on July 28, 2016).

Ashour, Omar. What Egyptians can learn from Turkey's Failed Coup, (Online), (http://www.aljazeera.com/indepth/opinion/2016/07/ egyptians-learn-turkey-failed-coup-160720142447097.html, accessed on July 30, 2016)

al-Azami, Usaama. Muslim Scholars and Autocrats (Part I). (Online), (http://www.huffingtonpost.com/usaama-alazami/muslim-scholarsand-autocrats_b_8865430.html, accessed on 30 July 2016).

al-Azami. Usaama. How Not to Disown 'Islamist' Terrorism. (Online), (http://www.huffingtonpost.com/usaama-alazami/how-not-todisown-islamis_b_8823864.html, accessed on 30 July 2016).

al-Azami. Usaama. Translation of Ali Jumas Lecture to the Egyptian Armed Forces. (Online), (https://www.academia.edu/19791977/ Translation_of_Ali_Jumas_Lecture_to_the Egyptian_Armed_Forces_Summer_2013, accessed on 30 July 2016).

Daily Sabah's report. Turkey's Opposition Parties Take Unified Stance against Coup Attempt. (Online), (http://www.dailysabah.com/ politics/2016/07/16/turkeys-opposition-parties-take-unified-stanceagainst-coup-attempt, accessed on 28 July, 2016).

Delkhasteh, Mahmood. Egypt: Secular Dictatorship vs. Religious Dictatorship, (Online), (http://www.huffingtonpost.com/mahmooddelkhasteh/egypt-secular-parites_b_3798852.html, accessed on 29 July 2016).

Emre, Yusuf. The Lessons to be Learned from Turkey's Failed Coup. (Online), (http://www.aljazeera.com/indepth/opinion/2016/07/ lessons-learned-turkey-failed-coup-160720085821212.html, accessed on July 28, 2016).

Fuller, Graham E.. The Gulen Movement Is Not a Cult — It's One of the Most Encouraging Faces of Islam Today. (Online), (http:// www.huffingtonpost.com/graham-e-fuller/gulen-movement-notcult_b_11116858.html, accessed on 28 July 2016).

Ismahan. Erdogan's Achievements in The Turkish Economy. (Online), (http://ar-rai.com/erdogans-achievements-in-the-turkisheconomy?lang=en, accessed on July 28, 2016).

Kingsley, Patrick. Egypt Suffering Worst Economic Crisis Since 1930. (Online), (https://www.theguardian.com/world/2013/may/16/egyptworst-economic-crisis-1930s, accessed on July 27, 2016)

Maass, Harold. Did Egypt's Military Manufacture An Economic Crisis to Sabotage Morsi? (Online), (http://theweek.com/articles/462268/ did-egypts-military-manufacture-economic-crisis-sabotage-morsi, accessed on July 28, 2016).

Shahine, Gihan. Risks to Al-Azhar?. (Online), (http:// weekly.ahram.org.eg/News/3403/32/Risks-to-Al-Azhar-.aspx, accessed on 30 July 2016)

Shapiro, Jeremy, The Coup Conundrum. (Online), (http:// www.brookings.edu/blogs/order-from-chaos/posts/2016/07/22- 
146 JURNAL HUBUNGAN INTERNASIONAL

VOL. 5 EDISI 2 / OKTOBER 2016-MARET 2017

turkish-coup-us-policy-shapiro, accessed on July 27, 2016).

Singh, Michael. Egypt's Economic Crisis: How to Help Cairo Help Itself

(Online), (http://www.washingtoninstitute.org/policy-analysis/view/ egypts-economic-crisis-how-to-help-cairo-help-itself, accessed on July 27, 2016).

Tremblay, Pinar. How Erdogan Used the Power of the Mosques against Coup Attempt. (Online), (http://www.al-monitor.com/pulse/ originals/2016/07/turkey-coup-attempt-erdogan-mosques.html, accessed on 30 July 2016)

Voa's News. Egypt's Morsi Brings More Islamists into Cabinet. (Online), (http://www.voanews.com/a/egypt-morsi-brings-more-islamistsinto-cabinet/1656125.html, accessed on September 28, 2016). 